\title{
PENERAPAN TEKNIK MODERASI TERHADAP IMPLEMENTASI MODEL PEMBELAJARAN MITIGASI BENCANA DI SEKOLAH DASAR
}

\author{
Syahrial A. ${ }^{1)}$, Kosim ${ }^{2)}$, ( Wayan Gunada ${ }^{3)}$ \\ 1)Program Studi Pendidikan Fisika, FPMIPA, Universitas Mataram, Mataram, NTB \\ Corresponding author: Syahrial A. \\ E-mail : syahrial_ayub@unram.ac.id
}

Diterima 17 Oktober 2021, Disetujui 06 November 2021

\begin{abstract}
ABSTRAK
Penelitian ini bertujuan untuk mengungkapkan tanggapan dan pendapat guru tentang pelaksanaan model pembelajaran mitigasi bencana dan upaya meningkatkannya di sekolah dasar. Penelitian dilaksanakan terhadap 12 guru SD negeri 1 Sembalun Lombok Timur, NTB. Penelitian deskriptif ini dimulai dengan menampilkan sebuah model pembelajaran mitigasi bencana tanah longsor oleh tim peneliti yang dilanjutkan dengan diskusi struktur pembelajaran mitigasi bencana yang diaplikasikan dari modeling sebelumnya. Hasil penelitian mendapatkan 5 pokok pikiran tentang pelaksanaan model pembelajaran mitigasi bencana tanah longsor, yaitu 1) mengkondisikan peserta didik menghadapi bencana alam dalam proses pembelajaran, 2) guru harus memiliki langkah yang tepat dalam memberikan pemahaman tentang bencana alam dan melakukan demontrasi langsung sehingga peserta didik memahami dengan seksama, 3) guru harus memiliki pengetahuan kebencanaan gempabumi, tsunami, tanah longsor, banjir, angin topan dan gunungapi, 4) guru memberikan contoh pembelajaran mitigasi bencana kepada peserta didik menggunakan alat bantu seperti video, alat mitigasi bencana dan lainnya, 5) pemahaman resiko/bahaya, kerentanan (kelemahan), ancaman dan kemampuan/kekuatan bencana tanah longsor.
\end{abstract}

Kata kunci: teknik moderasi; implementasi model pembelajaran mitigasi bencana; sekolah dasar.

ABSTRACT
This study aims to reveal the responses and opinions of teachers about the implementation of the
disaster mitigation learning model and efforts to improve it in primary schools. The study was conducted
on 12 teachers of SD Negeri 1 Sembalun, East Lombok, NTB. This descriptive study begins by
presenting a learning model for landslide disaster mitigation by the research team, followed by a
discussion of the disaster mitigation learning structure applied from the previous modeling. The results
of the study obtained 5 main ideas about the implementation of the landslide disaster mitigation learning
model, namely 1 ) conditioning students to face natural disasters in the learning process, 2) teachers
must have the right steps in providing an understanding of natural disasters and conducting direct
demonstrations so that students understand carefully, 3) teachers must have knowledge of earthquakes,
tsunamis, landslides, floods, hurricanes and volcanoes, 4) teachers provide examples of disaster
mitigation learning to students using tools such as videos, disaster mitigation tools and others, 5 )
understanding risk/hazard, vulnerability (weakness), threat and capability/strength of landslide disaster.

Keywords: moderation techniques; implementation of disaster mitigation learning model; primary school.

\section{PENDAHULUAN}

Pembelajaran mitigasi bencana bertujuan untuk meningkatkan kesadaran bahwa kita hidup di daerah rawan bencana. Periode Januari sd Oktober 2021 telah terjadi 2.007 kejadian bencana di Indonesia (BNPB, 2021). Bencana yang terjadi berupa gempabumi, tanah longsor, banjir dan lainnya serta bukan tidak mungkin akan terjadi bencana tsunami, gunung api atau angin topan. Analoginya sama dengan penggunaan sabuk pengaman di mobil, jika tidak dipakai tidak akan berguna sampai pada suatu kecelakaan mobil yang fatal. Artinya, kita tak tahu kapan kecelakaan itu datang, maka paling aman sabuk pengaman itu setiap kali kita berkendaraan mobil hendaknya dipakaikan. Begitu juga dengan informasi pengetahuan dan pembelajaran mitigasi bencana, hendaknya diberikan berkesinambungan, karena kejadiannya kapan, dimana dan seberapa besar dampak bencana sampai saat ini belum ada yang dapat memprediksi (Ramadhani, 2020). Pengetahuan dan pembelajaran mitigasi 
sangat perlu diberikan kepada guru dan peserta didik, agar terlatih tidak panik dalam meghadapi bencana dan dapat menyebarkan informasi mitigasi kebencanaan atau pengurangan resiko akibat bencana alam kepada masyarakat (Ayub, S., 2019). Makin besar kesiagaan masyarakat atas bencana yang mengancam, maka makin kecil resiko yang dihadapi (Rachmat, 2004). Guru dan peserta didik di sekolah dasar merupakan salah satu yang rawan terkena bencana, bukan hanya guru dan peserta didik saja tetapi masyarakat sekolah termasuk kepala sekolah dan pegawai. Sekolah sadar bencana dapat menjadi solusi dalam mengurangi resiko atau bahaya bencana di sekolah (DAPS-SEQIP, 2009). Saat ini, yang menjadi kendala dalam menumbuhkan sadar bencana di sekolah melalui pendidikan yang di implementasikan dengan model pembelajaran mitigasi bencana adalah belum masuknya mitigasi bencana di kurikulum pendidikan di Indonesia. Pemecahannya adalah dengan mengintegrasikan model pembelajaran mitigasi bencana di semua matapelajaran yang ada di sekolah dasar. Analisis kurikulum sekolah dasar yang sesuai dengan indikator dan tujuan pembelajaran mitigasi bencana yang akan di ajarkan, olehkarena itu diperlukan implementasi model pembelajaran mitigasi bencana di sekolah dasar. Model pembelajaran mitigasi bencana adalah model yang dikembangkan untuk guru dan peserta didik supaya mereka mempunyai kesadaran bencana yang memunculkan kesiapsiagaan dan di wujudkan dalam bentuk sikap atau perilaku sadar bencana. Perilaku sadar bencana diharapkan mampu meminimalkan korban jiwa, kerusakan lingkungan, kerugian harta benda dan dampak psikologis bagi yang terdampak. Peserta didik adalah anggota masyarakat yang berusaha mengembangkan potensi diri melalui proses pembelajaran pada jalur pendidikan (Ibrahim, 2010) dan menjadi objek atau yang akan mengalami dalam kegiatan ini, makanya model pembelajaran mitigasi bencana yang dikembangkan berorientasi kepada peserta didik (student oriented). Pembelajaran akan dilakukan oleh guru sehingga kegiatan implementasi model pembelajaran mitigasi bencana dilakukan kepada guru SD Negeri 1 Sembalun, Lombok Timur. Sekolah ini dilingkari oleh pegunungan yang ada di gunung Rinjani sehingga sangat rawan bencana.

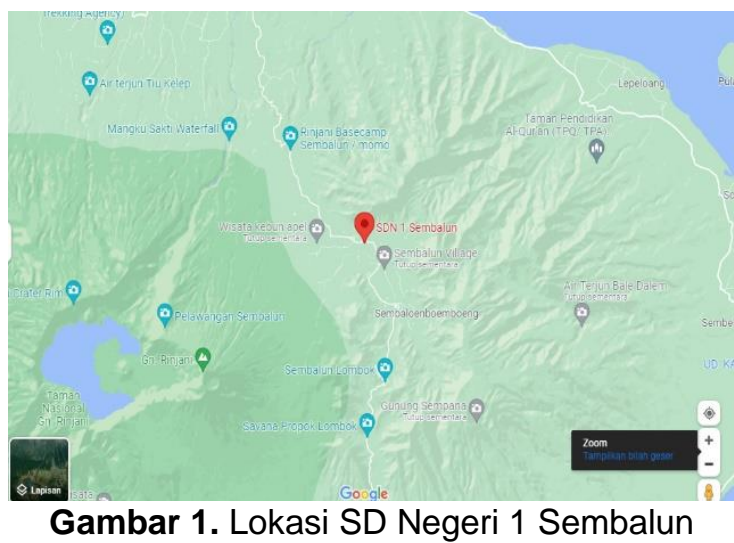

SD Negeri 1 Sembalun terletak di Sembalun Lawang, Sembalun Timba Gading kecamatan Sembalun Lombok Timur NTB. Sekolah ini terdampak gempabumi saat gempa Lombok tahun 2018 dengan kekuatan 7 SR, dan sangat rawan bencana alam lainnya seperti tanah longsor, gunungapi, banjir bandang dan angin topan. Inilah yang menjadi salah satu alasan tempat dilaksanakannya implementasi model pembelajaran mitigasi bencana sekolah dasar berikut tanggapan dan pendapat guru tentang model pembelajaran ini. Tanggapan dan pendapat guru berkenaan implementasi model pembelajaran mitigasi bencana ini akan diungkapkan dengan teknik moderasi. Teknik moderasi ini dapat digunakan oleh siapa saja yang ingin memecahkan masalah dan meminta pendapat/tanggapan dengan cara berdiskusi dalam kelompok yang mengutamakan keterlibatan aktif semua peserta dan mendapatkan hasil akhir yang efektif dan efisien. Dan metode moderasi ini dapat dilakukan, baik di dalam dunia kerja, bidang pendidikan maupun dalam masyarakat. Moderasi adalah suatu cara berdiskusi dalam kelompok yang mengutamakan keterlibatan aktif semua peserta untuk mendapatkan hasil akhir yang efektif dan efisien, dan merupakan sistem dari suatu teknik dan metode pelaksanaan diskusi kelompok yang membutuhkan pemandu (DAPS-SEQIP, 2009). Pemandu tersebut mengarahkan dan membidani pemecahan masalah atau alternatif pemecahan masalah serta meminta tanggapan/pendapat. Metode moderasi saat ini merupakan metode yang sangat populer karena telah terbukti kesuksesannya sebagai metode yang digunakan dalam kelompok dan juga sebagai salah satu instrumen untuk memperbaiki sikap kerja sama, motivasi dan kinerja guru serta kepala sekolah. Teknik moderasi sebagai metode yang menuntut keterlibatan aktif semua peserta memiliki tujuan antara lain mengarahkan pada kemampuan peserta dalam berkomunikasi secara vebal maupun non verbal, melatih kemampuan 
peserta untuk mengemukakan apa yang sedang dipikirkan berkaitan dengan tema yang dibahas, menumbuhkan kebiasaan untuk menvisualisasi komentar atau ide secara logis, meningkatkan sikap kerja sama, mengembangkan efisien dan efektivitas dalam berdiskusi, menumbuhkan kesadaran dalam melihat kondisi, menumbuhkan rasa percaya diri peserta dan mengarahkan pada kemampuan berpikir yang logis dan berkelanjutan. Hal yang membedakan teknik ini dengan teknik lain adalah tervisualisasinya ide, komentar, ungkapan yang dituangkan dalam tulisan, gambar, maupun simbol-simbol sederhana yang mudah dikenal peserta dengan bentuk-bentuk yang menarik dan yang utama adalah tersalurkannya semua ide, usulan dan pemikiran guru. Berikut dijelaskan ciri-ciri dari teknik moderasi, antara lain : (1) visualisasi, hal yang perlu diperhatikan untuk ini antara lain tersedianya alat bantu untuk keperluan moderasi, ide \& komentar dan ungkapan dituangkan secara visual melalui tulisan maupun simbol, pembuatan plakat yang terstruktur dan jelas (tulisan, bahan, gambar dsb.), adanya notula sebagai arsip maupun dokumen-dokumen yang sewaktu-waktu dapat digunakan, presentasi plakat saat pleno. (2) adanya interaksi aktif yang diatur dalam aturan pembicaraan melalui pertanyaan kartu, (3) perencanaan tahap moderasi (perkiraan waktu yang dibutuhkan dan strategi pelaksanaannya), aturan dalam teknik moderasi adalah semua peserta dituntut ikut berpartisipasi secara aktif, tulis gagasan / ide / pernyataan dengan singkat dan jelas maknanya dalam sebuah kartu, tulisan dalam kartu menggunakan huruf cetak, satu kartu berisi satu gagasan / satu ide / satu pernyataan, tidak melebihi 3 (tiga) baris dalam setiap kartu, tulisan besar dan gemuk (tidak kecil), tulisan dari kiri ke kanan, dari atas ke bawah, warna dan bentuk spidol harus sama, moderator tidak boleh membuang satu kartupun, bertanya, dan moderator harus memberi tanda jika ada perubahan peran moderator. Jadi, berdasarkan uraian ini dapat kita pahami bahwa teknik moderasi sangat tepat untuk menggali gagasan maupun komentar dari semua peserta dalam kelompok. Teknik moderasi awalnya digunakan oleh wirausaha di Jerman untuk meningkatkan kinerja dan pemasaran produk mereka. Teknik ini kemudian di adopsi ke dunia pendidikan. Teknik ini sangat ampuh untuk mendapatkan masukan dalam meningkatkan kualitas pendidikan diantaranya kinerja guru/kepala sekolah, kualitas pembelajaran, serta memecahkan masalah pendidikan lainnya. Kelebihan teknik ini adalah semua pendapat, ide atau saran dari peserta diskusi akan tertampung dan dihargai, sehingga semua akan merasa puas. Ada beberapa langkah yang harus dilakukan dalam teknik moderasi, yaitu 1) pendahuluan (pemaparan tentang masalah yang akan didiskusikan), 2) menanyakan kepuasan peserta terhadap apa yang akan didiskusikan, 3) menanyakan apakah perlu ditingkatkan atau tidak, 4) Meminta peserta menuliskan semua ide, saran dan masukan pada kartu, 5) mengkasifikasikan ide dan saran berdasarkan pokok-pokok pikiran, 6) menyatukan pokok-pokok pikiran dalam satu kalimat yang dapat mewakili pokok-pokok pikiran yang muncul, 7) menentukan prioritas yang akan dilanjutkan, 8) menentukan penanggungjawab dan waktu yang dibutuhkan untuk menyelesaikan masalahnya, seperti kondisi sekarang, kondisi yang diinginkan, penanggung jawab, waktu yang dibutuhkan untuk mencapai tujuannya (Tim Seqip, 2010). $\mathrm{Hal}$ inilah yang membuat tim tertarik untuk melakukan penelitian dengan judul "penerapan teknik moderasi terhadap implementasi model pembelajaran mitigasi bencana di sekolah dasar"

\section{METODE PENELITIAN}

Penelitian ini adalah penelitian deskriptif, yaitu metode yang dilakukan untuk mengetahui gambaran, keadaan, suatu hal dengan cara mendeskripsikannya sedetail mungkin berdasarkan fakta yang ada. Sugiyono (2017), deskriptif adalah metode yang digunakan untuk menggambarkan atau menganalisis suatu hasil penelitian tetapi tidak digunakan untuk membuat kesimpulan yang lebih luas. Untuk memperoleh hasil yang lebih akurat pada regresi berganda, maka perlu dilakukan pengujian asumsi klasik. Artinya penelitian ini hanya ingin mengetahui bagaimana keadaan variabel itu sendiri tanpa ada pengaruh atau hubungan terhadap variabel lain seperti penelitian eksperimen atau korelasi. Pengembangan model pembelajaran, terdapat banyak unsur yang membentuknya meliputi pendekatan yang digunakan, model pembelajaran yang dipilih, media pembelajaran yang mendukungnya, hingga langkah pengaplikasiannya di kelas (Suprapto, 2002). Penelitian deskriptif berusaha untuk mengungkap berbagai detail yang tidak tampak tersebut agar metode pembelajaran dapat diterangkan sejelas jelasnya dan bisa didapatkan berbagai data berharga yang dapat ditarik untuk penelitian selanjutnya atau digunakan untuk pengaplikasian terbaiknya (Disaptono, 2005). Langkah-langkah yang dilakukan untuk mengungkapkan tanggapan dan pendapat guru terhadap implementasi model pembelajaran mitigasi bencana di SD 
Negeri 1 Sembalun adalah: 1) Tim melakukan modeling pembelajaran mitigasi bencana dengan topik "Mengenal cara-cara menghadapi bencana alam tanah longsor". Tahapan ini, salah seorang anggota tim menjadi guru sekolah dasar, sedangkan guru SD Negeri 1 Sembalun menjadi peserta didik. Hal ini dimaksudkan tercipta kondisi yang nyata sebagaimana pembelajaran di dalam kelas, 2) setelah selesai kegiatan modeling tim bersama guru mendiskusikan struktur pembelajaran mitigasi bencana yang dikaitkan dengan model yang sudah ditampilkan pada langkah pertama tadi sehingga guru mendapatkan contoh yang nyata implementasi struktur pembelajaran mitigasi bencana yang sudah disusun, 3) melakukan teknik moderasi untuk mengungkapkan tanggapan dan pendapat guru tentang implementasi model pembelajaran mitigasi bencana, 4) guru melakukan peer teaching dan menampilkan model pembelajaran mitigasi bencana yang lain, 5) observasi, evaluasi dan refleksi kegiatan peer teaching yang dilakukan oleh guru, untuk memantapkan pemahaman guru tentang model pembelajaran mitigasi bencana. Teknik moderasi dilakukan untuk mengetahui tanggapan dan pendapat guru terhadap implementasi model pembelajaran mitigasi bencana di SD Negeri 1 Sembalun. Adapun langkah-langkah teknik moderasi yang dilakukan adalah : 1) tim memaparkan yang telah paparkan sebelumnya yaitu modeling model pembelajaran mitigasi bencana, diskusi struktur pembelajaran, peer teaching, observasi, evaluasi dan refleksi. Selanjutnya tim mengajukan pertanyaan:

(1), bagaimana tanggapan bapak/ibu terhadap implementasi model pembelajaran mitigasi bencana di sekolah dasar?

Pertanyaan ini tidak dijawab secara lisan oleh bapak/ibu guru, tetapi tim melukiskan 3 gambar emosi di papan tulis, yaitu:

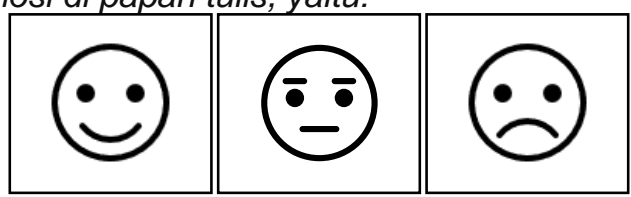

bapak/ibu diminta memilih sesuai dengan emosi yang dirasakan dengan cara memberikan tanda silang di kotak emosi. Melalui pertanyaan pertama, diperoleh informasi kepuasan guru terhadap implementasi model pembelajaran mitigasi bencana di SD Negeri 1 Sembalun. Apapun jawaban guru tidak menjadi masalah, karena akan ada pertanyaan berikutnya,

(2), perlu/tidak kegiatan implementasi model pembelajajaran mitigasi bencana di sekolah dasar ditingkatkan? pertanyaan kedua ini, dijawab langsung secara lisan oleh guru, naluri keguruan $100 \%$ guru akan menjawab "perlu ditingkatkan". Jawaban ini akan ada konsekuensinya karena akan ada pertanyaan berikutnya,

(3), hal-hal apa saja yang perlu ditingkatkan dalam implementasi model pembelajaran mitigasi bencana di sekolah dasar?

Pertanyaan ketiga ini tidak dijawab lisan oleh guru, tetapi tim memberikan beberapa kartu dimana di setiap kartu hanya berisi satu pokok pikiran tanggapan dan pendapat guru. Cara ini efektif untuk menjaring semua tanggapan dan pendapat guru tanpa kecuali, sehingga semua dapat mengemukakan tanggapan dan pendapatnya. Semua pendapat ditampung dan dihargai.

(4), tim mengelompokkan tanggapan dan pendapat guru sesuai dengan pokok pikirannya dengan membuat nomor 1, 2, 3, 4, dst. Setiap kartu yang berada di nomor tertentu berisi satu pokok pikiran, bila pokok pikiran baru harus berada di nomor yang berbeda.

(5), tim membimbing diskusi untuk merankai kata menjadi satu kalimat setiap tanggapan dan pendapat yang ada di setiap pokok pikiran yang terbentuk.

(6), tim membimbing diskusi untuk memecahkan permasalahan yang muncul dari tanggapan dan pendapat guru dengan membuat tabel pemecahan yang intinya berisi kondisi saat ini, kondisi sekarang, penanggung jawab, dan waktu yang dibutuhkan untuk menyelesaikannya. Selanjutnya tim dan guru akan terus berkomunikasi untuk mengatualisasi kan hasil teknik moderasi implementasi model pembelajaran mitigasi bencana di sekolah dasar. Berikut adalah foto-foto kegiatan penelitian di SD Negeri 1 Sembalun.

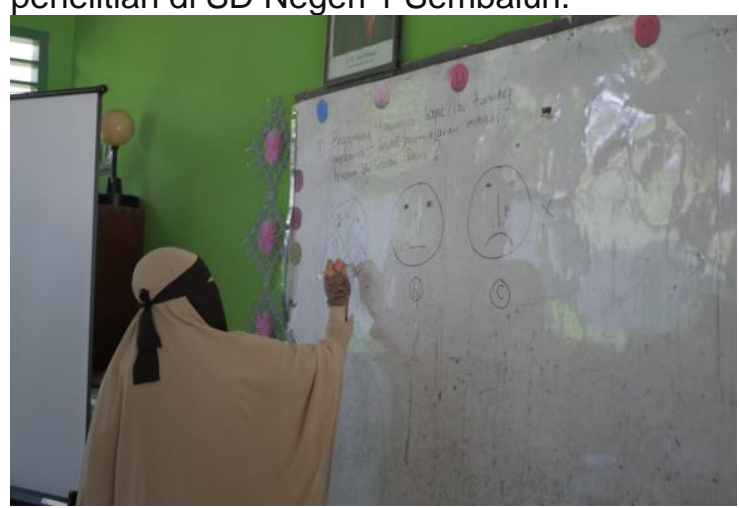

Gambar 2. Guru memilih sesuai emosinya dipertanyaan pertama 


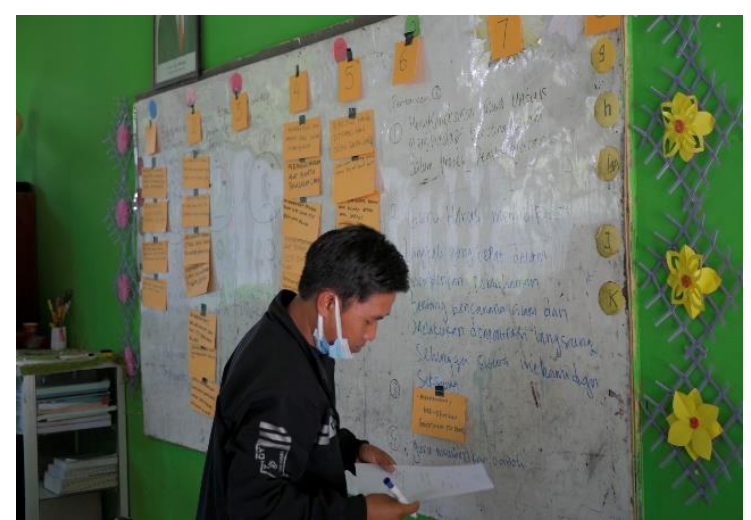

Gambar 3. Guru menulis kalimat yang mewakili pokok pikiran yang diusulkan

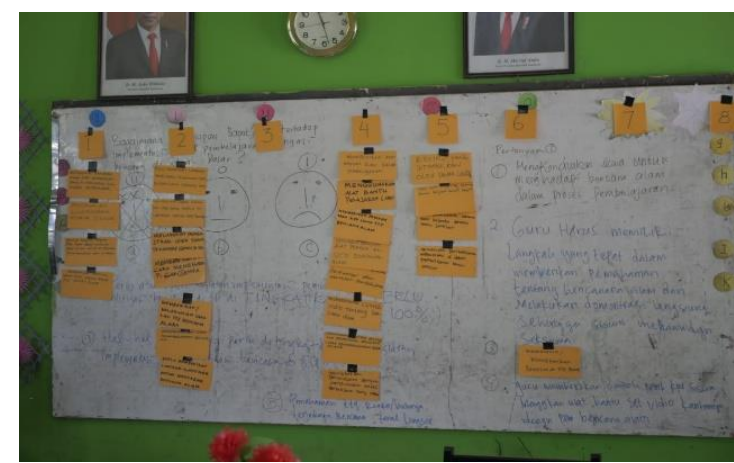

Gambar 4. Kartu-kartu usulan (zoop) yang ditempatkan sesuai pokok pikiran

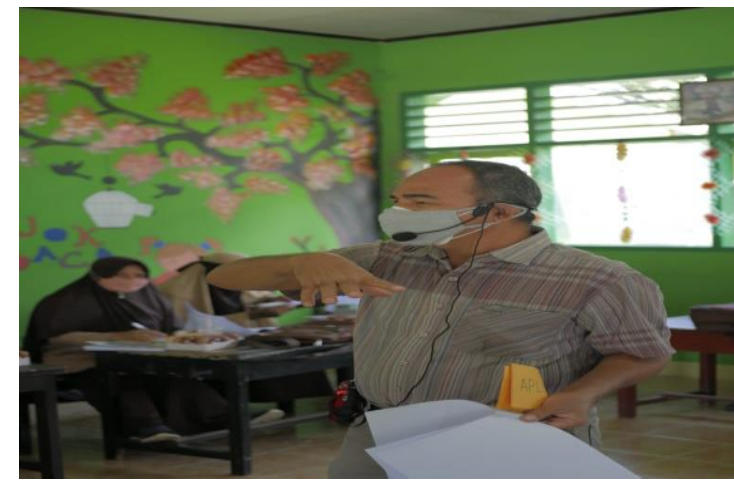

Gambar 5. Tim memimpin teknik moderasi

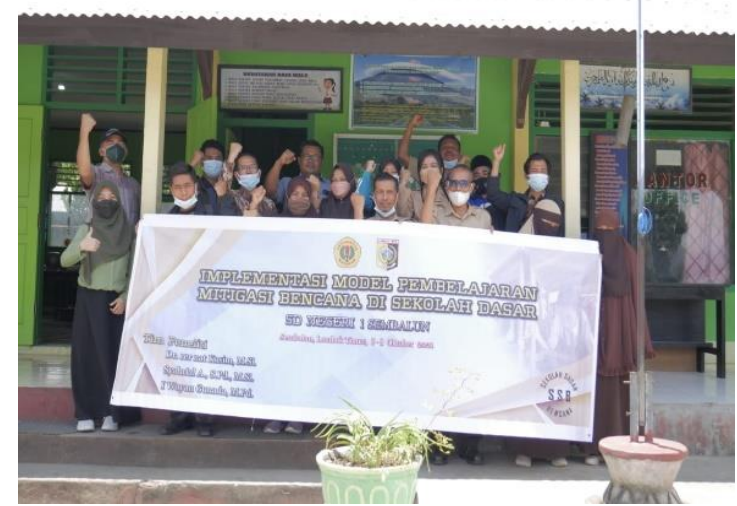

Gambar 6. Foto bersama tim dengan guru di depan SD Negeri 1 Sembalun

\section{HASIL DAN PEMBAHASAN Hasil Penelitian}

Teknik moderasi yang diterapkan kepada guru guru di SD Negeri 1 Sembalun mampu memaparkan apa adanya tanggapan dan pendapat guru terhadap implementasi model pembelajaran mitigasi bencana di sekolah dasar. Teknik ini menghargai semua usulan pemikiran dari guru, tidak ada guru yang tidak berpendapat sehingga dapat menjadi indikator bahwa hasil ini adalah suara hati guru SD Negeri 1 Sembalun. Hasil penelitian mendapatkan 5 pokok pikiran tentang pelaksanaan model pembelajaran mitigasi bencana tanah longsor, yaitu pokok pikiran 1) mengkondisikan peserta didik menghadapi bencana alam dalam proses pembelajaran. Pada pokok pikiran 1) ini terdapat tanggapan dan pendapat guru antara lain: (a) memberikan motivasi yang kuat dalam menarik minat peserta didik, (b) memilih langkah-langkah yang tepat dalam menarik minat peserta didik untuk mengetahui permasalahan yang akan dibahas, (c) pengenalan lingkungan kepada peserta didik, (d) mengenal karakter peserta didik dari permasalahan yang diharapkan guru. Pokok pikiran, 2) guru harus memiliki langkah yang tepat dalam memberikan pemahaman tentang bencana alam dan melakukan demontrasi langsung sehingga peserta didik memahami dengan seksama. Tanggapan dan pendapat guru pada pokok pikiran 2) adalah : (a) perlu memberikan langkah-langkah untuk mencegah bencana alam, (b) pengetahuan dan cara penanggulangan bencana, (c) memberikan atau melakukan simulasi tentang bencana alam, (d) memberi contoh cara menghadapi bencana, (e) melakukan demontrasi tentang cara-cara mitigasi bencana di kelas. Pokok pikiran, 3) guru harus memiliki pengetahuan kebencanaan gempabumi, tsunami, tanah longsor, banjir, angin topan dan gunungapi. Tanggapan dan pendapat guru pada pokok pikiran 3) adalah menambahkan dan meningkatkan pengetahuan tentang bencana alam. Pokok pikiran, 4) guru memberikan contoh pembelajaran mitigasi bencana kepada peserta didik menggunakan alat bantu seperti video, alat mitigasi bencana dan lainnya. Tanggapan dan pendapat guru pada pokok pikiran 4) adalah : (a) meningkatkan pembelajaran dengan model pembelajaran yang relevan, (b) memberikan contoh video tentang bencana alam, (c) penggunaan alat/media supaya peserta didik termotivasi, (d) memperbanyak alat peraga dan VCD bencana alam, (e) menggunakan alat bantu pelajaran. Pokok pikiran, 5) pemahaman resiko/bahaya, kerentanan (kelemahan), ancaman dan kemampuan/kekuatan bencana tanah longsor. 
Tanggapan dan pendapat guru pada pokok pikiran 5) adalah : (a) memahami pembelajaran implementasi di dalam pembelajaran bencana tanah longsor, (b) cara-cara mengurangi kemungkinan terjadinya tanah longsor, (c) resiko yang ditimbulkan oleh tanah longsor.

\section{Pembahasan}

Hasil penelitian menempatkan bencana tanah longsor menjadi sorotan utama karena menjadi salah satu pokok pikiran guru, hal ini dapat dikaitkan dengan lokasi sekolah yang berada di daerah pegunungan. Pegunungan sangat rentan dengan risiko bencana tanah longsor. Risiko adalah suatu kemungkinan untuk tertimpa bencana yang merupakan perbandingan antara besarnya ancaman dan kerentanan yang dibandingkan dengan kemampuan menanggulangi bencana (DAPSSEQIP, 2009). Secara matematika risiko dapat di formulasikan sebagai berikut :

$$
R=\frac{(A \times K)}{C}
$$

Dengan, $\mathrm{R}$ adalah risiko, $\mathrm{A}$ adalah ancaman atau bahaya, $\mathrm{K}$ adalah kerentanan atau kelemahan dan $\mathrm{C}$ adalah kemampuan atau kekuatan. Formulasi di atas menginformasikan untuk mengurangi risiko bencana maka kemampuan atau kekuatan harus ditingkatkan serta ancaman dan kerentanan di kurangi. Meningkatkan pemahaman terhadap pengertian tanah longsor, berbagai jenis, tanda tanda, serta dapat melakukan tindakan yang tepat pada saat dan setelah terjadi tanah longsor adalah salah satu upaya meningkatkan ketahanan atau kemampuan. Upaya yang dilakukan untuk meningkatkan ketahanan atau kemampuan adalah membangun fasilitas evakuasi di daerah aman di dekat area potensi tanah longsor, membangun fasilitas pertolongan SAR dan medis di kawasan aman serta membangun pusat logistik di tempat aman. Selain itu, upaya yang dapat dilakukan untuk mengurangi kerentanan atau kelemahan adalah stabilitas lereng, memberlakukan zonasi peruntukan lahan yang tepat, memberlakukan peraturan bangunan yang ketat, membangun dan menempatkan fasilitas ekonomi dan sosial yang vital di luar kawasan potensi tanah longsor, tidak membangun pemukiman di tepi tebing, tidak mencetak sawah baru dan kolam di lereng bagian atas dekat pemukiman, tidak menebang pohon di daerah lereng, tidak melakukan penggalian di bawah tebing, segera menutup rekahan dengan lempung dan membuat terasering di lereng pada daerah pemukiman atau sawah. Ancaman dapat juga di timbulkan oleh gempabumi, tsunami, letusan gunung merapi, banjir dan badai. Tingkatan ancaman dapat dikuantitatifkan dengan tanda-tanda akan terjadinya bencana. Tanda-tanda akan terjadinya tanah longsor antara lain munculnya mata air, rembesan, atau tanah yang jenuh dengan air yang tidak pernah terjadi sebelumnya, ada rekahan baru atau bulge (pembumbungan) yang tidak seperti biasanya yang terjadi di tanah, paving jalan, atau trotoar, tanah bergerak menjauhi pondasi bangunan, struktur-struktur tambahan seperti dek dan teras miring dan atau bergerak relatif terhadap struktur utama rumah, lantai beton dan pondasi miring atau mengalami rekahan, terjadi kerusakan pipa air dan fasilitas bawah tanah, tiang telepon, pohon, dinding penahan, atau pagar mengalami sedikit pergeseran atau miring, dan terjadi pergeseran pada kusen pintu. Tanda-tanda akan terjadinya bencana tanah longsor perlu diketahui untuk mengurangi ancaman. Bila ini dilakukan maka risiko bencana tanah longsor akan bisa di minimalkan, juga termasuk bencana yang lain seperti gempabumi, tsunami, banjir, gunung merapi dan angin topan. Lima pokok pikiran yang diungkapkan dengan teknik moderasi lainnya juga harus ditindaklanjuti. Petunjuk operasional pemecahan masalah yang diungkap penelitian ini harus di rumuskan supaya terjabarkan dengan jelas tata cara pemecahannya. Sebagai contoh pokok pikiran mengkondisikan peserta didik menghadapi bencana alam dalam proses pembelajaran. Dalam hal ini perlu dirumuskan kondisi saat ini, kondisi yang diharapkan, penanggungjawab dan waktu yang dibutuhkan untuk mencapainya. Sebaiknya petunjuk operasional pemecahan masalah ini dibuatkan dalam tabel sehingga mempermudah mengontrol pemecahan masalahnya.

Tabel 1. Petunjuk Operasional Pemecahan

$$
\text { Masalah }
$$

\begin{tabular}{lllll}
\hline No & Kondisi & Kondisi & $\begin{array}{l}\text { Penang } \\
\text { Saat ini } \\
\text { yang } \\
\text { diharapkan }\end{array}$ & $\begin{array}{l}\text { Waktu yang } \\
\text { dibutuhkan }\end{array}$ \\
\hline
\end{tabular}

Tabel petunjuk operasional pemecahan masalah ini juga harus di musyawarahkan atau dirapatkan oleh tim dan guru sehingga pokok pokok pikiran yang diungkapkan dapat diselesaikan dengan terarah dan sesuai tujuan. Implementasi model pembelajaran mitigasi bencana di SD Negeri 1 Sembalun saatnya nanti diharapkan mampu menjadikan Sekolah Sadar Bencana (SSB). Sekolah Sadar Bencana (SSB) memiliki masyarakat sekolah yakni guru, peserta didik, kepala sekolah dan pegawai sekolah mempunyai perilaku sadar 
bencana dan berinisiatif mengimbaskan kepada orang lain (Wibowo, 2019). Sesuai dengan (Widodo, E. 2014), penerapan perangkat pembelajaran dan model student oriented learning efektif terhadap meningkatkan kesadaran bencana peserta didik. Hal ini, sejalan dengan temuan bahwa respon guru dan peserta didik sangat baik terhadap perangkat pembelajaran mitigasi bencana, dan Suhardjo, D. (2011), paparan tentang pendidikan mitigasi bencana dalam rangka PRB (Pengurangan Risiko Bencana) sebagai berikut, wajib dilakukan melalui pendidikan formal dalam program Sistem Pendidikan Nasional (Diknas) dengan desain kurikulum dari Badan Standarisasi Nasional Pendidikan (BSNP). Kemudian, Ayriza, Yulia. (2011) menyimpulkan peningkatan yang signifikan pada keterampilan guru dalam melaksanakan layanan bimbingan pribadisosial dengan tujuan meningkatkan kesiapan psikologis siswa dalam menghadapi bencana alam antara sebelum dan sesudah pelatihan penerapan modul bimbingan, baik dalam membantu siswa memahami seluk beluk tentang bencana alam, mengelola afeksi siswa pada saat sebelum dan pasca bencana, serta keterampilan membimbing siswa menguasai berbagai prosedur dan keterampilan penyelamatan diri dalam situasi bencana. Tohani, E. (2019), penelitian ini menghasilkan temuan bahwa modal sosial memberikan kontribusi positif dalam mengembangkan masyarakat tahan bencana walau keberadaannya tidak disadari dalam kehidupan bermasyarakat. Dwiningrum, A.,I.,S., (2020), The resilience of students should be understood by the teacher. Teacher efforts to build and develop personal resilience because they are needed to build more effective school resilience. Resilience has the readiness to play a role in disaster mitigation. Disaster mitigation requires social synergy between the roles of principals, teachers, and students in order to build strong social cohesion. Wedyawati, $N$. (2017), terdapat perbedaan yang signifikan hasil belajar siswa kelas eksperimen dan kelas kontrol. Hasil analisis data angket menunjukkan model pembelajaran IPA terintegrasi mitigasi bencana sangat kuat. Muhammad A., (2019), menyimpulkan bahwa, materi pembelajaran PAI dalam Kurikukum 2013 terdapat pokok/sub pokok bahasan yang dapat diintegrasikan dengan wawasan mitigasi bencana alam. Agustiana, T., (2013), mendapatkan bahwa pemahaman dan ketahanmalangan siswa yang diajar dengan model pembelajaran mitigasi bencana lebih baik daripada pemahaman siswa yang diajar dengan model pembelajaran konvesional. A.Rusilowati , (2012), produk lima fitur model pembelajaran seperti: Silabus, RPP, metode pembelajaran, bahan ajar, serta teknik dan jenis asesmennya yang dikembangkan meliputi materi IPA kelas IV, V,VI SD dan VII, VII, IX SMP. Dari hasil desiminasi menunjukkan bahwa perangkat pembelajaran yang dikembangkan layak diberikan kepada siswa, dan dapat meningkatkan pemahaman siswa dalam mengenali dan menangani bencana. Yerizon, (2020), pengembangan perangkat pembelajaran berbasis model discovery learning yang berorientasikan mitigasi bencana alam, dapat menjadi solusi untuk memperkenalkan kepada peserta didik SMP/ MTsN tentang mitigasi bencana alam. Hasilhasil penelitian yang dipaparkan sebelumnya menunjukkan perangkat pembelajaran dan alat mitigasi bencana memberikan kontribusi yang signifikan pada pengetahuan, keterampilan, dan sikap peserta didik dalam mitigasi bencana, sehingga diharapkan mampu menimbulkan kesadaran bencana peserta didik.

\section{UCAPAN TERIMAKASIH}

Terima kasih tim mengucapkan kepada Kementerian Pendidikan, Kebudayaan, Riset dan Teknologi yang telah membiayai penelitian ini, Universitas Mataram yang telah menfasilitasi tim dalam melakukan penelitian ini dan bapak ibu guru SD Negeri 1 Sembalun atas kesediaan dan kerjasamanya selama pelaksanaan penelitian.

\section{DAFTAR RUJUKAN}

Ayub, S. (2019). Model Pembelajaran Kesiapsiagaan Gempabumi di Sekolah Dasar. Jurnal Orbita Universitas Muhammadyah Mataram, 5(2), 65-72. doi:

https://doi.org/10.31764/orbita.v5i2.118 $\underline{7}$

A. Rusilowati . (2012). Mitigasi Bencana Alam Berbasis Pembelajaran Bervisi Science Environment Technology and Society. Jurnal Pendidikan Fisika Indonesia. 8(1), 51-60. Retrived from. https://doi.org/10.15294/ipfi.v8i1.1994

Ayriza, Y. (2011). Peningkatan Keterampilan Guru Bimbingan Konseling dalam Pemerolehan Kesiapan Psikologis Siswa Menghadapi Bencana Alam. Jurnal IImiah Pendidikan Cakrawala. 2(2011), 230-242. Retrived from https://doi.org/10.21831/cp.v0i2.4230

Agustiana, T. (2013). Pengaruh Model Pembelajaran Mitigasi Bencana terhadap Pemahaman dan Ketahanmalangan Siswa. Jurnal Pendidikan dan Pengajaran. 46(2), 97105. Retrived from. 
http://dx.doi.org/10.23887/jppundiksha. v46i2\%20Juli.2660

BNPB. (2021). Update Bencana Alam Tahun 2021. Jakarta: Badan Nasional Penanggulangan Bencana

DAPS - SEQIP. (2009). Materi Pelatihan Banjir Modul I -5. Jakarta : GTZ-Dcpartcmen Pcndidikan Nasional Direktorat Pembinaan TK clan SD.

DAPS - SEQIP. (2009). Materi Pelatihan Tanah Longsor Modul 1-5. Jakarta : GTZDepartemen Pendidikan Nasional Direktorat Pcmbinaan TK dan SD.

DAPS - SEQIP. (2009). Materi Pclatihan Gcmpa Bumi Modul 1-5. Jakarta : GTZDepartemen Pendidi kan Nasional Direktorat Pembinaan TK dan SD.

DAPS - SEQTP. (2009). Materi Pelatihan Tsunami Modul 1-5. Jakarta : GTZDepartemen Pendidikan Nasional Direktorat Pembinaan TK dan SD.

Diposaptono S. (2005). Tsunami Mitigation Technology. Jakarta: Republic of Indonesia Maritime and Fisheries Agency Tsunami Mitigation Training Material.

Dwiningrum, A.,I.,S. (2020). School Strategies in Strengthening Student Resilience in Disaster-Prone Areas. Jurnal Ilmiah Pendidikan Cakrawala. 39(3), 720-731. Retrived from https://doi.org/10.21831/cp.v39i3.3024 $\underline{9}$

Diposaptono, S. (2005). Tsunami Mitigation Technology. Jakarta: Republic of Indonesia Maritime and Fisheries Agency Tsunami Mitigation Training Material.

Djamarah. (2005). Teachers and Students in Educative Interaction, A Psychological Theoretical Approach. Jakarta: Rineka Cipta.

Ibrahim, M. (2000). Problem Based Learning. Surabaya: University Press

Klinger, Walter. (1997). Survey of Teaching Methods in Natural Sciences. Erziehungswiss. Fakultat der Universtat: Erlangen-Nurnbe.

Muhammad, A. (2019). Pengembangan Materi Pendidikan Agama Islam (PAI) Berwawasan Mitigasi Bencana Alam pada Sekolah Menengah Pertama (SMP) di Kota Palu. Jurnal Diskursus Islam. 7(3), 453-465. Retrived from. http://103.55.216.56/index.php/diskurs us islam/article/view/12681/pdf

Ramadhani, R. M., Gustaman, F. A. I., Kodar, M. S., \& Widanaha, I. K. (2020). Implementasi Program Sekolah Aman Bencana Di Sekolah Menengah
Kejuruan Negeri 4 Balikpapan Kalimantan Timur. Jurnal Pendidikan IImu Pengetahuan Sosial Indonesia, 7(2), 162-176.

Sugiyono. (2017). Qualitative Quantitative Research Methods and $R$ \& $D$. Bandung: Alfabeta.

Suprapto S. (2002). Flood Disaster, Material for Disaster Power Training. Yogyakarta : PSBA UGM.

Suhardjo, D. (2011). Arti Penting Pendidikan Mitigasi Bencana dalam Mengurangi Resiko Bencana. Jurnal Ilmiah Pendidikan Cakrawala. 2(2011), 174188. Retrived from https://doi.org/10.21831/cp.v0i2.4226

Tohani, E., Wibawa, L. (2019). The Role of Social Capital in Disaster Management of Disaster Vulnerable Village Community on The Merapi Eruption. Jurnal Ilmiah Pendidikan Cakrawala. 38(3), 527-538. Retrived from https://doi.org/10.21831/cp.v38i2.2182 1

Wibowo, S., \& Sudarsono, A. (2017). Pemahaman Menejemen Bencana Siswa Smp Di Kabupaten Sleman. Jipsindo, 4(1), 1-21. doi:https://doi.org/10.21831/jipsindo.v4i 1.14834

Widodo, E., Widowati, A., Suyoso. (2014). Model Revitalisasi Sekolah Terdampak Erupsi Merapi melalui Pembuatan Perangkat Pembelajaran Inovatif Berbahan Dasar Limbah AnOrganik. Jurnal IImiah Pendidikan Cakrawala. 2(2014), 277-285. Retrived from. https://doi.org/10.21831/cp.v2i2.2167

Wedyawati, N. (2017). Pengaruh Model Pembelajaran IPA Terintegrasi Mitigasi Bencana Terhadap Hasil Belajar. Jurnal Pendidikan. 15(2), 261-273. Retrived from. http://dx.doi.org/10.31571/edukasi.v15i 2.636

Yerizon, (2020). Pengembangan Perangkat Pembelajaran Berbasis Model Pembelajaran Discovery Learning pada Mataeri Matematika Berorientasi Mitigasi Bencana. Jurnal Gantang. 5(1), 69-76. Retrived from. https://doi.org/10.31629/jg.v5i1.1898 